\title{
Effect of summer storms on early life stages of Uca minax, $U$. pugnax and $U$. pugilator in North Inlet Estuary, South Carolina, USA
}

\author{
Jenice Godley ${ }^{1}$, Renae Brodie ${ }^{2, *}$ \\ ${ }^{1}$ Department of Biological Sciences, University of South Carolina, Columbia, South Carolina 29208, USA \\ ${ }^{2}$ Biology Department, Mount Holyoke College, 50 College Street, South Hadley, Massachusetts 01075, USA
}

\begin{abstract}
Estuarine fiddler crabs have a complex life cycle that spans vastly different salinity regimes. Larvae are spawned in estuaries and travel to the coastal ocean where development takes place; after metamorphosing to the megalopal stage, fiddler crabs reinvade estuaries where they settle and metamorphose. In the coastal ocean, larvae experience relatively stable physical conditions; however, upon reinvading estuaries, they are exposed to great fluxes in salinity and temperature. In this study, we measured shifts in the salinity regime caused by storm events, and determined the impact of these changes on species frequencies of megalopae from 3 Uca species in the water column and of their recently settled juvenile crabs on the benthos along a salt marsh creek in South Carolina. Adults of the 3 species examined are found in different salinity regimes: adult Uca pugnax generally occupy areas with relatively high salinity and plant cover, while $U$. minax are found in low salinity or freshwater areas; $U$. pugilator are found in open sandy areas over a broad range of salinities, but generally occupy higher salinity environments than U. minax. For megalopal stages in the water column, we found that the relative proportions of the 3 species changed significantly along salinity gradients and in response to storm events. When the salinity regime normalized, species frequencies for megalopae returned to pre-storm proportions. Only $U$. minax megalopae were present in the water column during a storm event in July, whereas $U$. pugnax had been the most abundant species in the water column prior to the storm. Although all 3 species were able to survive storm events as juveniles, $U$. pugnax juveniles survived low salinity conditions significantly better than the other 2 species during the July storm. During a less severe storm in August, which lasted $5 \mathrm{~d}$ and altered the existing profile for a week, the benthic juvenile stages did not exhibit significant changes in species frequencies. Our results show that the duration and severity of salinity change are important variables that impact on the presence of these Uca species in the water column, and suggest that the physiology and behavior of the megalopal stage strongly influence where populations occur within estuaries.
\end{abstract}

KEY WORDS: Salinity $\cdot$ Tolerance $\cdot$ Uca spp. $\cdot$ Estuarine crabs

\section{INTRODUCTION}

Salinity impacts the distribution (Gunter 1956), biodiversity (Duke et al. 1998), recruitment (Forward et al. 2001) and survival (Sandison 1966) of estuarine organisms. Odum (1988) and Vernberg (1993) noted that freshwater flow from rain events altered the existing assemblage of organisms in an estuary, and stated that more studies need to be conducted on salinity because it affects the vast majority of estuarine biota. In this study, we investigated the impact of salinity changes on estuarine fiddler crabs belonging to the species Uca minax, $U$. pugnax and $U$. pugilator in the North Inlet Estuary, South Carolina (see Fig. 1). Specifically, we determined the impact of salinity gradients along tidal creeks and fast salinity changes associated with rain events on the relative abundance of megalopal and juvenile crabs within each of these species; ultimately, 
this investigation allowed us to explore how changes in species frequencies of early life stages under shifting salinity regimes could lead to changes in the distribution of these species across the marsh landscape.

Like most estuarine invertebrates, fiddler crab (UCa spp.) have complex life cycles that include life stages that occupy different habitats. The adults live and spawn in the estuary (salinity range from 0 to $32 \mathrm{psu}$ ) and larvae are dispersed into the coastal ocean (salinity $\sim 35 \mathrm{psu}$ ) where larval development is completed. Fiddler crab megalopae (also known as post-larvae) reinvade the estuary and find suitable benthic habitats by settling in response to environmental cues (O'Connor \& Epifanio 1985, Christy 1989, O'Connor 1993). Once inside the estuary, megalopae and early juvenile crabs may experience large changes in ambient salinity, especially during rainstorms when tidal creeks become inundated with runoff, which they cannot avoid because they cannot dig burrows to shield themselves from the extremes in salinity. Young crabs might be more sensitive to changes in ambient salinity, compared with adults who can dig burrows to the water table and who have more mature osmoregulatory systems.

Fiddler crabs are ideal for investigating the impact of salinity shifts on population distributions for several reasons: they show interspecific and intraspecific differences in salinity tolerance, and the different life stages live in different salinity regimes. They are also often abundant and play important ecological roles in the marsh assemblage (e.g. Crane 1975, Bertness 1985, Petit \& Bildstein 1987). Teal (1958) observed different distributions of Uca minax, U. pugnax and U. pugilator in a Georgia salt marsh, and suggested that salinity tolerances and preferences of the adult crabs were one of the major factors affecting the distribution of these species. In this study, we investigated the impact of salinity gradients along tidal creeks and quick changes in ambient salinity on early life stage fiddler crabs, in order to determine if these salinity changes impact species distributions within marsh ecosystems.

In many crab species, large shifts in salinity have been found to delay development, retard growth, alter larval behavior and reduce survival ( Sandoz \& Rogers 1944, Laughlin \& Neff 1981, O'Connor \& Epifanio 1985, Forward et al. 1996, Anger 2003), and this is generally true of estuarine invertebrates (e.g. Innes \& Haley 1977, Rayner 1979, Saranchova \& Flyachinskaya 2001, Ushakova 2003). In an earlier study that also involved invertebrates from the North Inlet Estuary, changes in salinity that mimicked storm action reduced growth rates and survival of the larvae of a marine polycheate Arenicola cristata and a mud snail Ilyanassa obsoleta in the laboratory (Richmond \& Woodin 1996, 1999). Increases in the mortality of the early life stages may lead to recruitment failure at existing adult habitats (Heck et al. 2001), and may limit the inland distribution of estuarine species; for example, Guerin \& Stickle (1997) explained the distribution of 2 Callinectes species along salinity gradients below 10 psu based on the salinity tolerances of their juvenile stages.

In this study, we used Polymerase Chain ReactionRestriction Fragment Length Polymorphism (PCRRFLP) to identify field-caught early life stage crabs to species level. In this way, we were able track the proportional changes of the 3 fiddler crab species under naturally changing salinity conditions in the field, which we measured with a data-logger.

\section{MATERIALS AND METHODS}

Field sites. This study was conducted from June to August 2003 in the North Inlet Estuary near Georgetown, South Carolina (33⒚0' N, 79¹1.6' W). North Inlet is a small, highly saline estuary that is well mixed and shallow (average $3 \mathrm{~m}$ depth) with an average tidal height of $1.5 \mathrm{~m}$ (Christy \& Morgan 1998, Potthoff \& Allen 2003). Swimming megalopae were collected just before the nocturnal high tide from the water column at Clam Bank Bridge and at 3 sites along Oyster Creek (1400 $\mathrm{m}$ in length) along a salinity gradient (Fig. 1): Hell Site, Little Pool, and Oyster Landing. Hereafter, the aforementioned sites on Oyster Creek will be referred to as the low, medium and high salinity sites, respectively.

Collection of planktonic (pre-settled) megalopae. Megalopae swimming in the water column were captured using light traps (35 cm diameter, $18 \mathrm{~cm}$ height) constructed of $6.5 \mathrm{~mm}$ acrylic sheets with Styrofoam glued on the top for floatation. Four trapping chambers (0.5 cm openings) and a net, with a glow stick as the light source, acted as a collecting chamber beneath the trap. Our light traps were designed by M. Reichert et al. (unpubl.) and were based on the quatrefoil light trap design (Floyd et al. 1984). The most significant changes to Floyd et al.'s (1984) design were triangular rather than cylindrical chambers, a (chemical) light stick rather than a battery operated light source, and a mesh net rather than a stainless steel pan to collect the catches (M. Reichert pers. comm.). The traps were deployed $1 \mathrm{~h}$ before high tide and retrieved $1 \mathrm{~h}$ later for 6 nights during July 2003. Three traps were used at each site along Oyster Creek (9 traps in total for each night sampled), and 2 traps were deployed at Clam Bank Bridge for each night sampled. After the traps were retrieved, megalopae were removed from each trap and preserved in 95\% ethanol for identification using PCR-RFLP analysis. The samples from the 
3 traps at each site were combined and analyzed as 1 sample; this was done to ensure that we had a large enough sample size for each site. The PCRRFLP protocol (Behum et al. 2005, Brodie et al. 2005) allowed us to differentiate among the 3 Uca species at any life stage.

Collection of benthic (settled) early life stages. Early life stage Uca spp. (megalopae and juveniles up to $3.4 \mathrm{~mm}$ carapace width) were collected from the exposed benthos during low tide at the low salinity site and Clam Bank Bridge (Fig. 1). Specimens were collected 4 times a week, weather permitting, during July and August 2003 from exposed sediment at the low salinity site and Clam Bank Bridge during low tide. Approximately 12 specimens were collected from each of 3 areas within each sampling site $\left(\sim 36\right.$ ind. site $\left.{ }^{-1}\right)$ and preserved in $95 \%$ ethanol. Although we sampled benthic juveniles at regular intervals, only those collected from the sediment before, during and after 2 storm events were identified using PCR-RFLP due to the expense of this procedure.

Adult distributions were assessed once during the course of this study, using a mean number of 9 randomly placed $1 \mathrm{~m}^{2}$ quadrats at each site, in order to obtain a general idea of species abundance. These data were used to determine which, if any, of these species dominated each field site and are

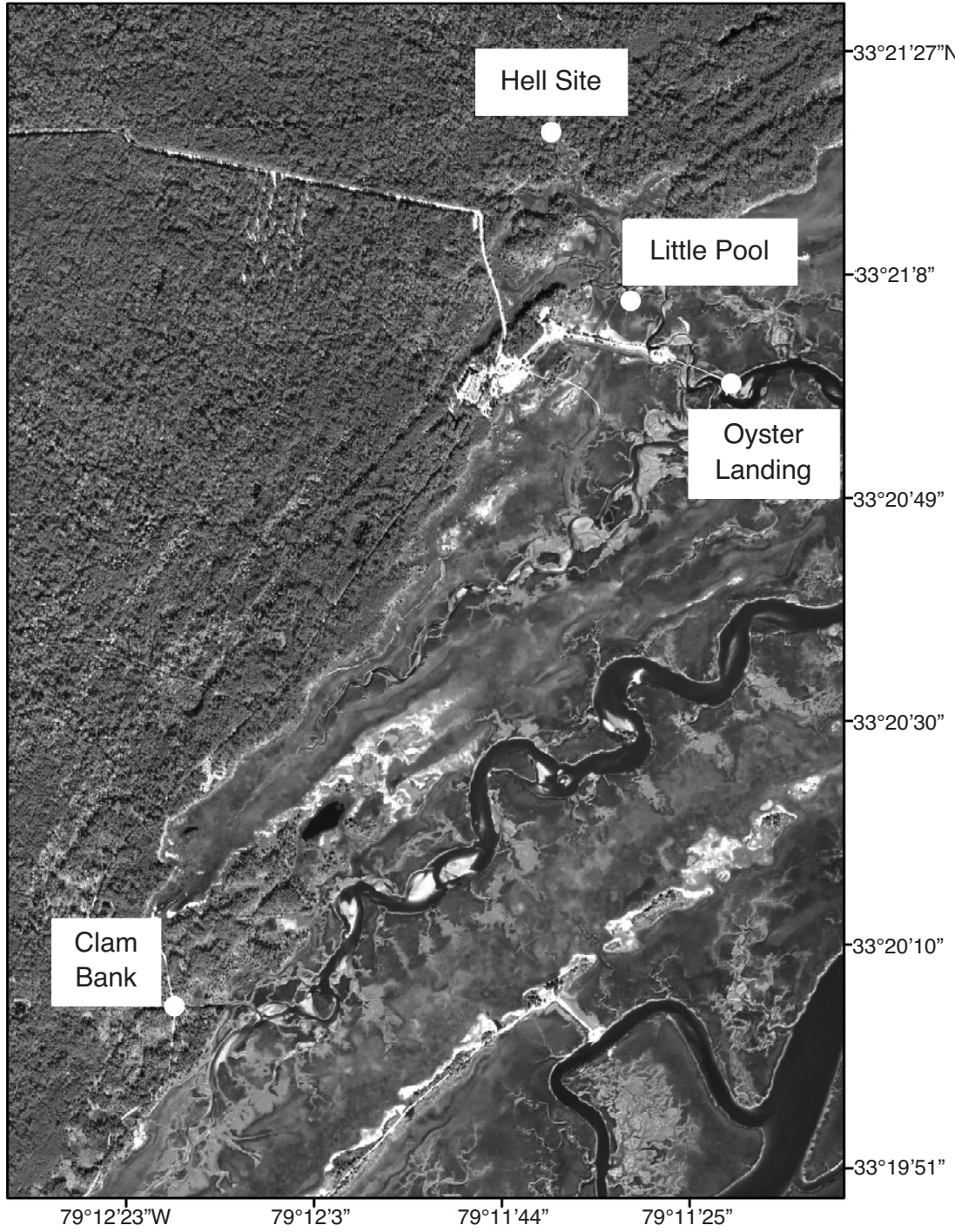

Fig. 1. Field sites in North Inlet Estuary, South Carolina included here to characterize the sites.

Salinity data. A UNIDATA Starlogger Micrologger with a conductivity probe (model 6536C - Four Electrode Conductivity) was used to record salinity and temperature. The probe was placed approximately $2 \mathrm{~cm}$ above the sediment in the tidal creek channel at the low salinity site and Clam Bank Bridge. The loggers sampled conductivity every $12 \mathrm{~s}$ and a mean was calculated and recorded every $10 \mathrm{~min}$. Salinity data collection began June 25, 2003 for the low salinity site and July 1, 2003 for Clam Bank Bridge, and data collection ended August 31, 2003 at both sites.

Salinity data for the high salinity site, as well as meteorological data, were obtained from the National Estuarine Research Reserve Site (NERRS) at the Baruch Marine Field Lab (BMFL). A YSI 6000 datalogger was used to collect salinity data every $30 \mathrm{~min}$ from the high salinity site. Rain data were collected every 15 min during a rain event at the high salinity site using a Campbell Tipping Bucket Rain Gauge (Campbell Scientific).

Statistical analysis. A chi-square analysis was used to compare species proportions of megalopae in the water column along the salinity gradient and to examine frequency changes before and after major rain events for both megalopae and juveniles.

\section{RESULTS}

\section{Adult species distributions}

The medium and the high salinity sites had semidiurnal tidal signals and were characterized by Spartina alterniflora-covered habitats as well as open, sandy 
areas. Adult UCa pugnax and U. pugilator dominated these sites, while $U$. minax was the most abundant at the low salinity site. The low salinity site was a wooded drainage area $4.2 \mathrm{~km}$ from the mouth of the estuary where a freshwater creek and a tidal creek (Oyster Creek) merged. It was an area that experienced predominately diurnal tides that ranged from 0.2 to $1.4 \mathrm{~m}$ in height; however, mixed tidal signals were noted on

Table 1. Rain and salinity (mean \pm SD) for North Inlet Estuary and sampled sites during summer (July-August) 2003. Hell Site (low salinity site) and Oyster Landing (high salinity site) are along Oyster Creek, and Clam Bank Bridge is on Bly Creek. Dates are mm/dd

\begin{tabular}{|lcccc|}
\hline Period & $\begin{array}{c}\text { Rain total } \\
(\mathrm{mm})\end{array}$ & $\begin{array}{c}\text { Hell Site } \\
\text { (psu) }\end{array}$ & $\begin{array}{c}\text { Oyster Landing } \\
\text { (psu) }\end{array}$ & $\begin{array}{c}\text { Clam Bank } \\
\text { Bridge }(\mathrm{psu})\end{array}$ \\
\hline 06/24 to 06/28 & 0.1 & $3.8 \pm 10$ & nd & nd \\
06/29 to 07/05 & 16.6 & $15.9 \pm 5$ & $27.3 \pm 2$ & $20.2 \pm 7$ \\
07/06 to 07/12 & 16.1 & $17.0 \pm 9$ & $31.0 \pm 3$ & $23.1 \pm 6$ \\
07/13 to 07/19 & 82.6 & $21.2 \pm 8$ & $31.7 \pm 3$ & $14.5 \pm 3$ \\
$07 / 20$ to 07/26 & 98.5 & $0.2 \pm 0.1$ & $11.8 \pm 8$ & $4.4 \pm 2$ \\
$07 / 27$ to 08/02 & 7.8 & $0.62 \pm 1$ & $20.9 \pm 9$ & $5.5 \pm 3$ \\
$08 / 03$ to 08/09 & 14.2 & $5.1 \pm 7$ & $29.9 \pm 3$ & $14.1 \pm 13$ \\
08/10 to 08/16 & 3.1 & $19.5 \pm 5$ & $33.1 \pm 2$ & $23.8 \pm 11$ \\
$08 / 17$ to 08/23 & 33.3 & $2.4 \pm 4$ & $24.5 \pm 5$ & $10.5 \pm 10$ \\
08/24 to 08/31 & 0.0 & $19.1 \pm 8$ & $30.6 \pm 4$ & $21.5 \pm 10$ \\
Range & $0-155.2$ & $0.03-33.3$ & $0.3-36.2$ & $0.001-34$ \\
July & 219.2 & $11.2 \pm 11$ & $24.8 \pm 10$ & $13.3 \pm 9$ \\
August & 51.2 & $11.1 \pm 10$ & $29.5 \pm 5$ & $17.0 \pm 12$ \\
Summer & 270.4 & $10.9 \pm 10$ & $27.2 \pm 8$ & $15.2 \pm 11$ \\
\hline
\end{tabular}

several occasions. Adult U. minax (34 ind. $\mathrm{m}^{-2}$, authors' pers. obs.) were found here on muddy substratum covered primarily by the marsh plants Juncus roemerianus and Distichlis spicata, while adult U. pugilator (8 ind. $\mathrm{m}^{-2}$, authors' pers. obs.) were found in open, sandy patches. Clam Bank Bridge was also a transitional area from an upland pine forest to a salt marsh with characteristic $S$. alterniflora-covered areas and mud flats. This site was $4 \mathrm{~km}$ from the mouth of the estuary and experienced semidiurnal tides. The adult fiddler crabs of each species exhibited preferences for different micro-habitats at Clam Bank Bridge: the open, muddy areas were inhabited by $U$. minax (16 ind. $\mathrm{m}^{-2}$, authors' pers. obs.), the open, sandy areas were populated with $U$. pugilator (16 ind. $\mathrm{m}^{-2}$, authors' pers. obs.), and the $S$. alterniflora ridges and banks were inhabited by adult $U$. pugnax (19 ind. $\mathrm{m}^{-2}$, authors' pers. obs.); in addition, mixed flocks roved around the open sand and mudflats.

\section{Salinity}

From July to August 2003, 270 mm of rain was recorded at North Inlet, with the greatest amount of rainfall

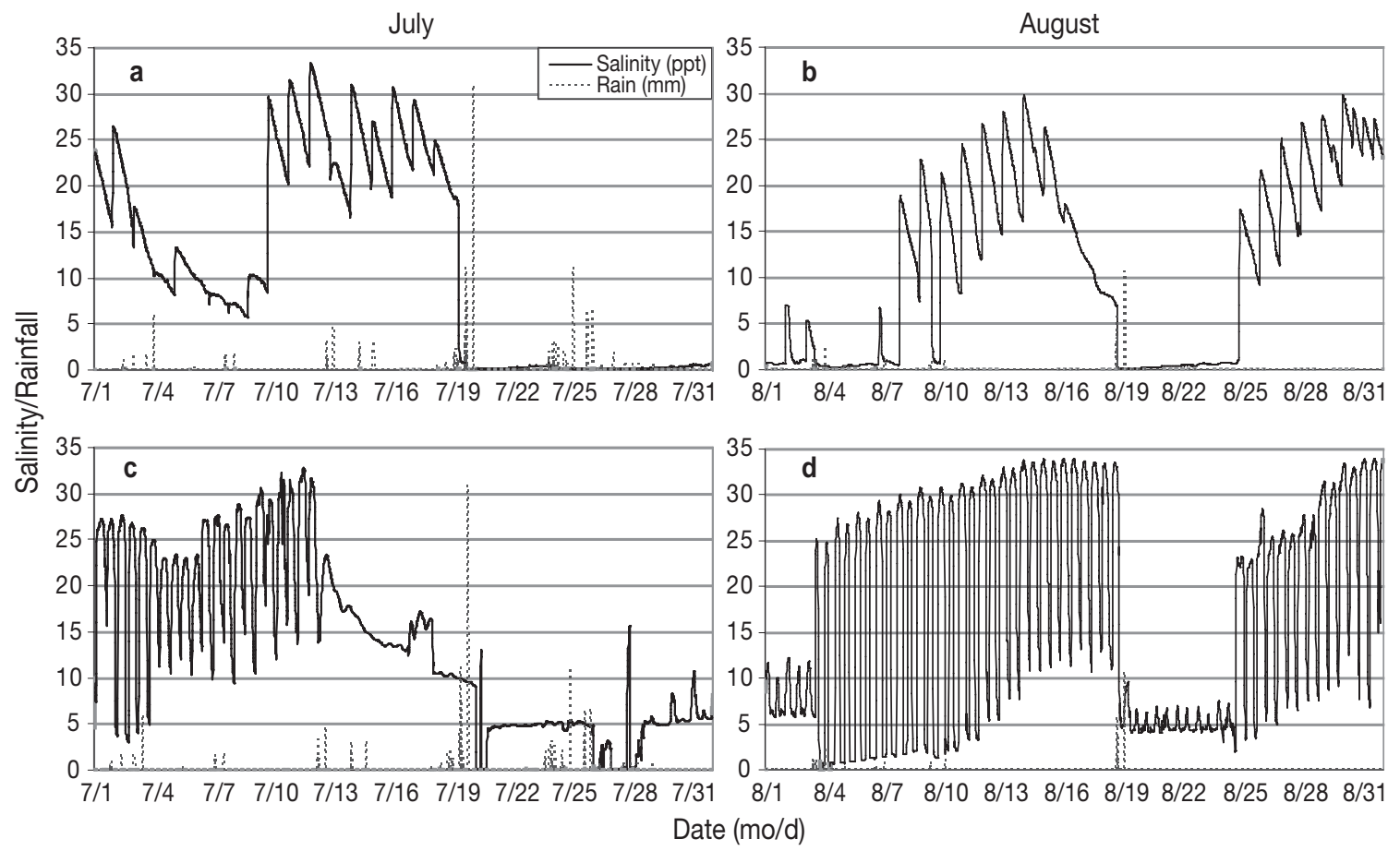

Fig. 2. Salinity profiles and rain data for (a,b) Hell Site (low salinity site) and (c,d) Clam Bank Bridge during July and August 2003 
occurring in July $(219.2 \mathrm{~mm})$. Most of this rain (181 mm) fell during an $8 \mathrm{~d}$ period from July 19 to July 26, during which there was a corresponding drop in salinity at the Oyster Creek and Clam Bank Bridge field sites (Table 1). Between July 20 and 26 the average salinity was 0.2 psu for the low salinity site, $11.8 \mathrm{psu}$ for the high salinity site and $4.4 \mathrm{psu}$ for Clam Bank Bridge, while the July monthly average for each site was 11.2, 24.8 and 13.3 psu, respectively. A large rain event also occurred during the week of August 17 to 23, when $33.3 \mathrm{~mm}$ was recorded (Table 1).

These storms changed the existing salinity profiles at the field sites, which led to a spatial shift in salinity at both the low salinity site and Clam Bank Bridge. Spatial shifts in salinity are not uncommon when rain storms take place in an estuarine environment (Duke et al. 1998). The intensity of the shifts in salinity varied by rainfall amount and by site (Fig. 2). During July's major storm event (July 19 and 20), the amount of rainfall was $82 \mathrm{~mm}$, more than double that of the August storm. The rain events caused a severe reduction in the average salinity at the low salinity site, the high salinity site and Clam Bank Bridge. At each site the reduction in salinity was longer lasting following large rainfalls (July) than after smaller rain events (August). The latter is especially true for the sites furthest inland inland (the low salinity site and Clam Bank Bridge), where fresh water runoff further reduced salinity (Fig. 2, Table 1).

\section{Distribution of megalopae and juveniles}

We observed highly significant differences in proportions of megalopal species along Oyster Creek (Fig. 3), such that a shift in megalopal species dominance from Uca pugnax to $U$. minax occurred along the salinity gradient $\left(\chi^{2}=184, \mathrm{p}<0.0005\right.$, df $\left.=4\right)$, especially between the medium and the low salinity sites. At the high salinity site, approximately $90 \%$ of the megalopae in the water column were $U$. pugnax, which is the dominant adult fiddler species in this area (authors' pers. obs.). The remaining 10\% of megalopae were either U. pugilator, U. minax, or a mixture of both of these species (Fig. 3). At the medium salinity site, there was a small increase $(\sim 20 \%)$ in the relative proportion of $U$. pugilator and $U$. minax in the water column, with a corresponding decrease in U. pugnax, indicating that $U$. pugnax was leaving the water column faster than the other 2 species. At the low salinity site, a major shift was seen in the species proportions of megalopae in the water column, such that $U$. minax comprised $>90 \%$ of the megalopae on 3 of the 4 nights sampled.

The distribution of planktonic megalopae along the salinity gradient in Oyster Creek was consistent in that Uca pugnax dominated in higher salinity areas, and $U$. minax in lower salinity areas, over the entire sampling period (Fig. 3); however, the position of the zone of $U$. minax dominance shifted inland during periods of low rainfall (July 14), and downstream towards the inlet

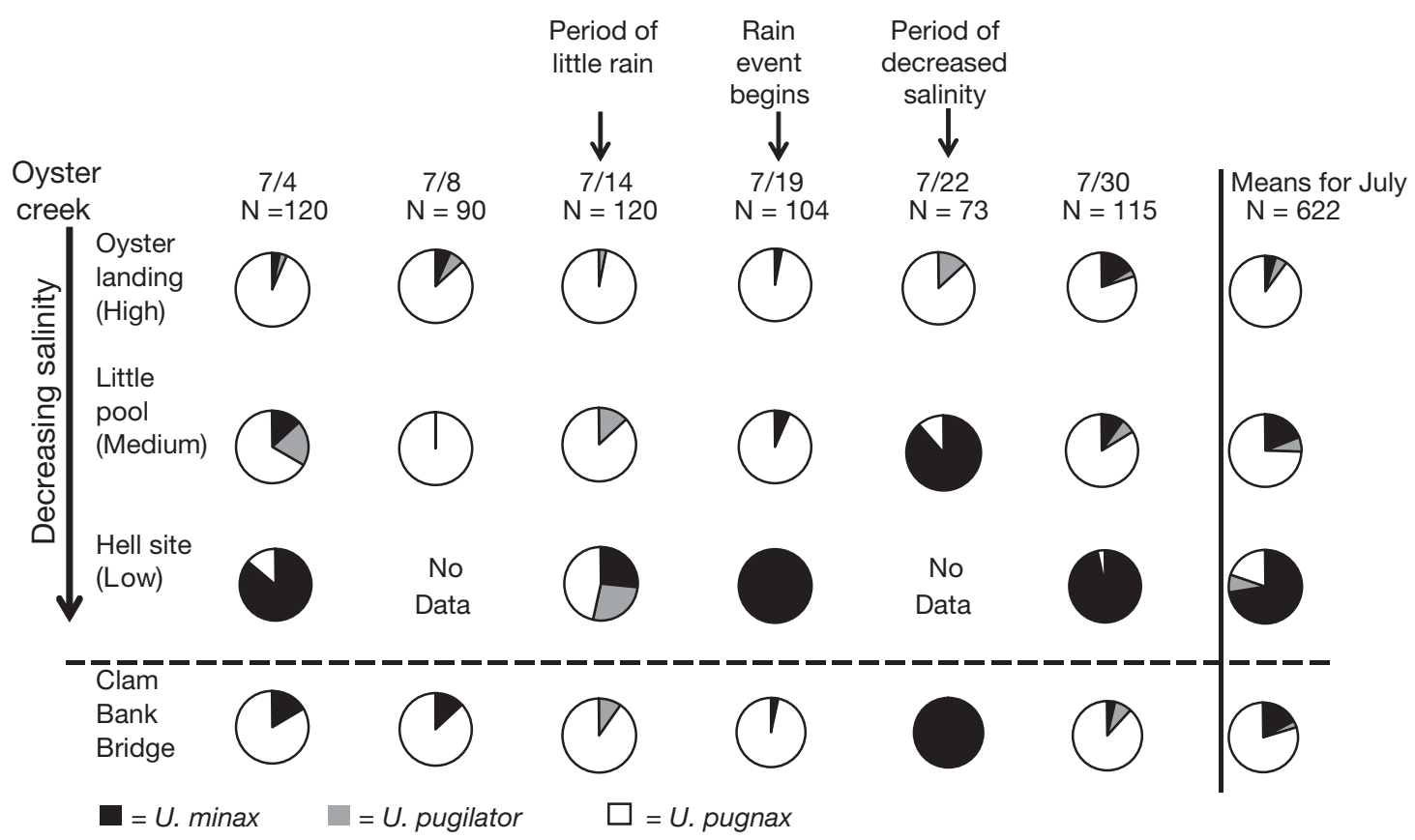

Fig. 3. UCa spp. Megalopal species proportions in the water column along a decreasing salinity gradient in Oyster Creek, and at Clam Bank Bridge on Bly Creek, July 2003. Dates are mo/d 


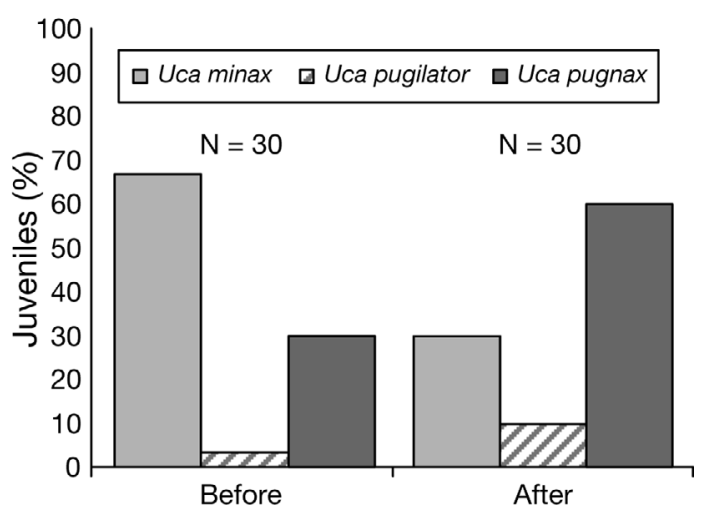

Fig. 4. Uca spp. Frequency of juveniles collected from Clam Bank Bridge before $(\mathrm{N}=30)$ and after $(\mathrm{N}=30)$ a July 2003 storm event

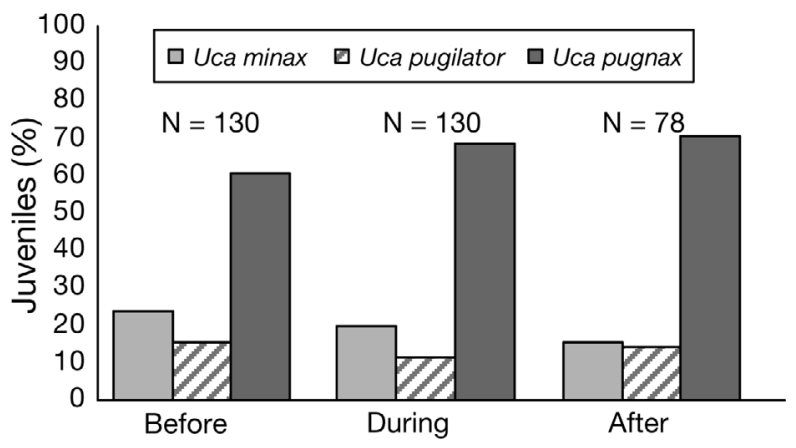

Fig. 5. Uca spp. Frequency of juveniles collected from Clam Bank Bridge before $(\mathrm{N}=130)$, during $(\mathrm{N}=130)$ and after $(\mathrm{N}=$ 78) a storm event in August 2003

during periods of greater rainfall (July 19 and 22; Figs. $2 \& 3$ ). Changes in species proportions may have occurred because $U$. minax survived better than the other 2 species when salinities were reduced; also, the downstream drift of $U$. minax megalopae from more inland sites during these freshets may have contributed to an increased representation of this species at Clam Bank Bridge and the medium salinity site in Oyster Creek.

To investigate if a reduction in salinity would further affect benthic juvenile species distributions, we examined periods before, during and after 2 major rain events. In July, $181 \mathrm{~mm}$ of rain was recorded in a $2 \mathrm{wk}$ period (Table 1), which caused a reduction in salinity of nearly $3 \mathrm{wk}$ duration (Fig. 2). At Clam Bank Bridge, we observed a clear shift in species dominance, from a preponderance of settled Uca minax juveniles before the rain event to a preponderance of settled U. pugnax juveniles after the event $\left(\mathrm{N}=60, \chi^{2}=8.17, \mathrm{p}<0.05\right.$, $\mathrm{df}=2$; Fig. 4). In contrast, a much smaller (33.3 mm) rain event in August caused a 6 d reduction in salinity (Fig. 2) but resulted in no change in benthic juvenile

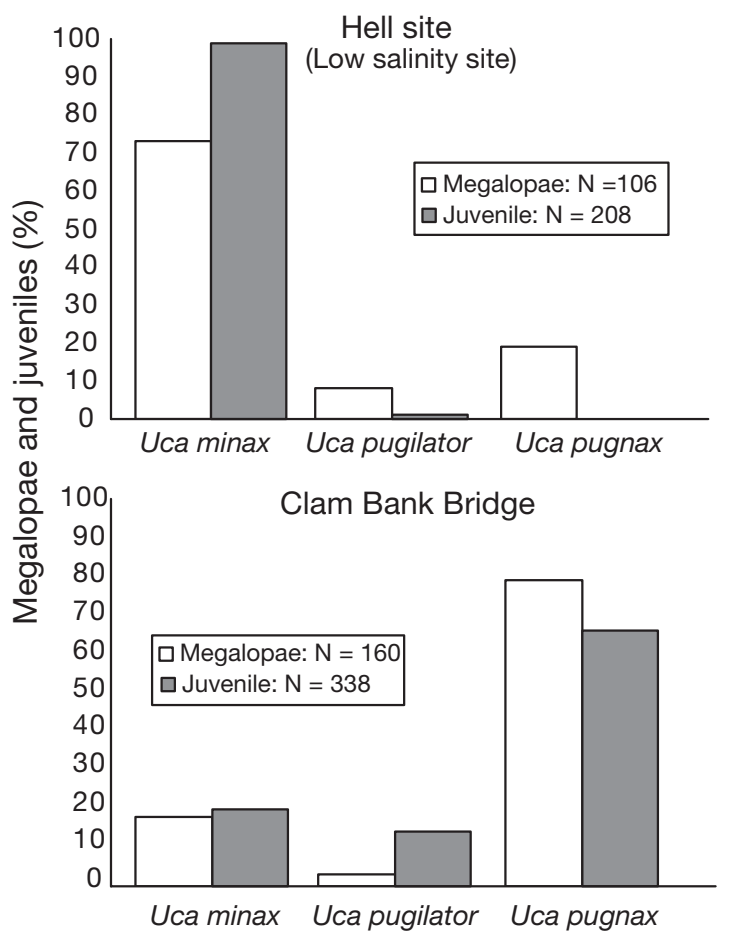

Fig. 6. Uca spp. Comparison of planktonic megalopae in the water column (low salinity site: $N=106$; Clam Bank Bridge: $\mathrm{N}=160$ ) with juveniles settled on the benthos 1 mo later (low salinity site: $\mathrm{N}=208$; Clam Bank Bridge: $\mathrm{N}=338$ )

distribution ( $\mathrm{N}=338, \chi^{2}=0.67, \mathrm{p}>0.05, \mathrm{df}=2$; Fig. 5) Thus, the duration of rain/salinity events appears to be an important influence on the success of settled juvenile UCa spp. Only U. minax settled successfully at the low salinity site along Oyster Creek during the study period; therefore, the before-, during- and after-storm assessment of juvenile species distributions was not conducted for this site.

Planktonic megalopal species abundances differed significantly from benthic juvenile species abundances 1 mo later at Clam Bank Bridge $\left(\chi^{2}=20.4, p<0.0005\right.$, $\mathrm{df}=2$; Fig. 6) and the low salinity site $\left(\chi^{2}=56.7\right.$, $\mathrm{p}<0.0005$, df $=2$; Fig. 6). At Clam Bank Bridge, the species present in the water column as megalopae were also present on the benthos as settled juveniles, but this was not the case at the low salinity site. At the low salinity site along Oyster Creek, Uca pugnax and $U$. pugilator megalopae were present in the water column during high salinity periods; however, no $U$. pugnax and only $1 U$. pugilator were found in the 208 benthic juvenile specimens identified from this site (Figs. 2, 3 \& 6). The low salinity site experienced $3 \mathrm{wk}$ of $\sim 1$ psu salinity during July and August, and these extremely low salinity conditions clearly prevented the successful settlement of $U$. pugnax and $U$. pugilator, even though megalopae of these species arrived at this site. As for the higher salinity Clam Bank Bridge site, 
$U$. pugnax planktonic megalopae were dominant except during a period of 5 psu salinity (Figs. 2, 3 \& 6), and they remained dominant as settled benthic juveniles. This suggests a threshold in the neighborhood of $5 \mathrm{psu}$, below which U. pugnax megalopae and/or juveniles suffer catastrophic mortality.

\section{DISCUSSION}

This study was carried out to examine the influence of summer storms on the distribution of planktonic megalopae and newly settled juveniles of 3 fiddler crab species in the field. Adults of these species are distributed differentially along salinity gradients, and it has long been assumed that adult behavior and physiological tolerance determines the distribution pattern (Teal 1958, Crane 1975, Thurman 2002). In our study, we observed that these fiddler crab species are also distributed differentially along salinity gradients as megalopae in the water column, with Uca pugnax dominating in higher salinity areas and $U$. minax in lower salinity areas. And although this pattern remained evident during and after rain events, the location of $U$. pugnax- and $U$. minax-dominated areas shifted along tidal creeks. These clear, rapid changes in relative abundance of planktonic megalopae of Uca minax, U. pugnax and U. pugilator may have indicated a direct response of megalopae to salinity in the water column. Megalopae of U. pugilator and U. pugnax may suffer high mortalities at lower salinities or they may settle out of the water column in areas closer to the mouth of the estuary in response to the spatial shift in salinity caused by freshwater influx (Forward et al. 2001). This latter scenario is supported by O'Connor \& Epifanio (1985), who inferred from their data that megalopae seek out adult conspecific salinity regimes. Megalopae of $U$. pugnax and U. pugilator may also have responded behaviorally by moving to the bottom of the water column and clinging onto sea grass or other objects to avoid the top-most, fresher layer of the water column where we collected our samples by light trap. Finally, a spatial shift of the entire assemblage may have occurred as freshwater runoff pushed the planktonic community towards the inlet.

The survival and therefore the successful recruitment of benthic juveniles is more clearly correlated with salinity changes than with physical displacement by runoff from rain events, because these minute benthic stages would not likely shift position along a tidal creek during a rain storm. Juveniles of all 3 species were more robust in their responses to rapid changes in salinity than megalopae. The juvenile species proportions of Uca minax, U. pugilator and U. pugnax did not change significantly before, during or after the storm event at Clam Bank Bridge during the $3 \mathrm{wk}$ period studied in August. However, for the July storm, there were changes in juvenile species proportions that favored $U$. pugnax. This finding is perplexing, because adult $U$. pugnax are known to flourish in areas of the marsh that are highly saline, whereas adult, juvenile and megalopal $U$. minax are found in low salinity and freshwater habitats. Although juvenile $U$. pugnax appeared to do better than the other 2 species at salinities down to $5 \mathrm{psu}$, the exposure to low salinities may have still damaged the survivors (however, this was not examined in this study). For example, juveniles of other estuarine crab species have been found to have delayed intermolts and exhibit stunted growth when exposed to salinities lower than optimal (Laughlin \& Neff 1981, Guerin \& Stickle 1997). Uca pugnax juvenile density was unaffected by week-long salinity reductions as low as $5 \mathrm{psu}$; however, 3 weeks of $<1$ psu resulted in the exclusion of $U$. pugnax benthic juveniles, despite the presence of $U$. pugnax planktonic megalopae comprising $20 \%$ of the planktonic population at the low salinity site (Fig. 6).

In this study, we found that summer storms that alter salinity regimes affect recruitment success; thus, summer rainfall patterns may help to explain yearly changes in community composition. For example, during 2002 and 2003, we observed a shift in adult species composition at the low salinity site. In the summer of 2002 , approximately $50 \%$ of the adult Uca spp. population consisted of $U$. minax, while the juveniles collected were comprised of $52 \% U$. $\operatorname{minax}, 45 \% U$. pugilator and $3 \% U$. pugnax (Brodie et al. 2005). In the summer of 2003, almost $100 \%$ of the juveniles sampled were $U$. minax (Fig. 6), and the ratio of adult $U$. minax to $U$. pugilator was 3:1 (authors' unpubl. data). The main difference between these 2 years is that 2002 was the last year of a $5 \mathrm{yr}$ drought that broke in 2003. The rain events of 2002 did not accumulate as much rain per event, and the pattern of rainfall differed between 2002 and 2003: in 2002, there were several weeks during which there was little to no rainfall, resulting in fairly constant salinity profiles for those weeks. In contrast, it rained in all but 1 week of July and August of 2003, and several major salinity regime shifts occurred during this period. Thus, salinity at the low salinity site was much lower in 2003 than in 2002, which likely caused a greater recruitment of $U$. minax that became evident in the adult population during 2003.

Our study suggests that the timing of rain events has a large impact on differential recruitment and survival. If small rain events occur sporadically during periods of recruitment, there would be less of an impact on recruitment into established adult populations because the existing salinity profiles would remain stable. However, more frequent and severe rain events 
throughout the recruitment period could have an adverse effect on the recruitment of some species, because the salinity profiles would be in constant flux due to the input of freshwater into the system. In this case, a spatial shift in salinity would impact existing species' distribution. Our study also suggests that some life stages within a species are more susceptible to the impacts of summer storms than others. These stages should be the focus of field collections and salinity tolerance experiments if inferences are to be drawn about physiological tolerances and species distributions. The greatly significant difference in proportional changes of species observed at the megalopal stage suggests that this stage may be the evolutionarily 'weakest link' of the lifecycle, which establishes where Uca minax, $U$. pugnax and $U$. pugilator are able to recruit along a salinity gradient.

Acknowledgements. We thank Matt Behum, Josette Wiggins, Kharyee Butler and Steven Borgianini for their cheerful assistance with field work under grueling conditions. We are also greatly indebted to staff at the Baruch Marine Field Laboratory (BMFL), in particular Dennis Allen, Paul Kenny, Stephen Forehand and Ginger Matthews. Marcel Reichert generously loaned us light traps, which he designed. Finally, we thank David Wethey and 2 anonymous reviewers for helpful comments on earlier versions of this manuscript. This study was funded by NSF IBN 0237484 and start-up funding from the University of South Carolina, Department of Biological Sciences. This is Contribution No. 1444 from BMFL.

\section{LITERATURE CITED}

Anger K (2003) Salinity as a key parameter in the larval biology of decapod crustaceans. Invertebr Reprod Dev 43: 29-45

Behum ME, Brodie RJ, Staton JL (2005) Distribution of juvenile UCa pugnax and U. pugilator across habitats in a South Carolina estuary, assessed by molecular techniques. Mar Ecol Prog Ser 288:211-220

Bertness MD (1985) Fiddler crab regulation of Spartina alterniflora production on a New England salt marsh. Ecology 66:1042-1055

Brodie RJ, Behum ME, Monroe E, Glenn N, Staton JL (2005) Recruitment to adult habitats following marine planktonic development in the fiddler crabs, Uca pugilator, Uca pugnax and Uca minax. Mar Biol 147:105-111

Christy JH (1989) Rapid development of megalopae of the fiddler crab Uca pugilator reared over sediment: implications for models of larval recruitment. Mar Ecol Prog Ser 57: 259-265

Christy JH, Morgan SG (1998) Estuarine immigration by crab megalopae: mechanisms, reliability and adaptive significance. Mar Ecol Prog Ser 174:51-65

Crane J (1975) Fiddler crabs of the world. Princeton University Press, Princeton, NJ

Duke NC, Ball MC, Ellison JC (1998) Factors influencing biodiversity and distributional gradients in mangroves. Global Ecol Biogeogr 7:27-47

Floyd KB, Courtenay WH, Hoyt RD (1984) A new larval fish light trap: the quatrefoil trap. Prog Fish Cult 46:216-219

Forward RB Jr, DeVries MC, Rittschof D, Frankel DAZ, Bischoff JP, Fisher CM, Welch JM (1996) Effects of envi-

Editorial responsibility: Gareth Harding,

Dartmouth, Nova Scotia, Canada ronmental cues on metamorphosis of the blue crab Callinectes sapidus. Mar Ecol Prog Ser 131:165-177

Forward RB, Tankersley RA, Rittschof D (2001) Cues for metamorphosis of brachyural crabs: an overview. Am Zool 41: 1108-1122

Guerin JL, Stickle WB (1997) A comparative study of two sympatric species within the genus Callinectes: osmoregulation, long-term acclimation to salinity and the effects of salinity on growth and moulting. J Exp Mar Biol Ecol 218: 165-186

Gunter G (1956) Some relations of faunal distributions to salinity in estuarine water. Ecology 37:616-619

Heck KL Jr, Coen LD, Morgan SG (2001) Pre- and post-settlement factors as determinants of juvenile blue crab Callinectes sapidus abundance: results from the north-central Gulf of Mexico. Mar Ecol Prog Ser 222:163-176

Innes DJ, Haley LE (1977) Genetic aspects of larval growth under reduced salinity in Mytilus edulis. Biol Bull (Woods Hole) 153:312-321

Laughlin RB Jr, Neff JM (1981) Ontogeny of respiratory and growth responses of larval mud crabs Rhithropanopeus harrisii exposed to different temperatures, salinities and naphthalene concentrations. Mar Ecol Prog Ser 5:319-332

O'Connor NJ (1993) Settlement and recruitment of the fiddler crabs Uca pugnax and U. pugilator in a North Carolina, USA, salt marsh. Mar Ecol Prog Ser 93:227-234

O'Connor NJ, Epifanio CE (1985) The effect of salinity on the dispersal and recruitment of fiddler crab larvae. J Crustac Biol 5:137-145

Odum WE (1988) Comparative ecology of tidal freshwater and salt marshes. Annu Rev Ecol Syst 19:147-176

Petit DR, Bildstein KL (1987) Effect of group size and location within the group on the foraging behavior of white ibises. Condor 89:602-609

Potthoff MT, Allen DM (2003) Site fidelity, home range, and tidal migrations of juvenile pinfish, Lagodon rhomboides, in salt march creeks. Environ Biol Fish 67:231-240

Rayner SM (1979) Comparison of the salinity range tolerated by teredinids (Mollusca: Teredinidae) under controlled conditions with that observed in an estuary in Papua New Guinea. Aust J Mar Freshw Res 30:521-533

Richmond CE, Woodin SA (1996) Short-term fluctuations in salinity: effects on planktonic invertebrate larvae. Mar Ecol Prog Ser 133:167-177

Richmond CE, Woodin SA (1999) Effect of salinity reduction on oxygen consumption by larval estuarine invertebrates. Mar Biol 134:259-267

Sandison EE (1966) The effect of salinity fluctuations on the life cycle of Balanus pallidus stutsburi Darwin in Lagos Harbour, Nigeria. J Anim Ecol 35:363-378

Sandoz M, Rogers R (1944) The effect of environmental factors on hatching, moulting, and survival of zoea larvae of the blue crab Callinectes sapidus Rathbun. Ecology 25:216-228

Saranchova OL, Flyachinskaya LP (2001) The influence of environmental salinity on early ontogenesis of the mussel Mytilus edulis and the starfish Asterias rubens from the White Sea. Mar Biol 27:110-116

Teal JM (1958) Distribution of fiddler crabs in Georgia salt marshes. Ecology 39:185-193

Thurman CL (2002) Osmoregulation in six sympatric fiddler crabs (genus Uca) from the Northwestern Gulf of Mexico. PSZN I: Mar Ecol 23:269-284

Ushakova OO (2003) Combined effect of salinity and temperature on Spirorbis spirorbis L. and Circeus spirillum L. larvae from the White Sea. J Exp Mar Biol Ecol 296:23-33

Vernberg FJ (1993) Salt-marsh processes: a review. Environ Toxicol Chem 12:2167-2195

Submitted: May 6, 2005; Accepted: September 29, 2006

Proofs received from author(s): July 11, 2007 